\title{
Design of Sewage Treatment Plant for Dr. TTIT Campus
}

\author{
Syed Ariff ${ }^{1}$, Aamina Rizwan ${ }^{2}$, Akshaya.K $^{3}$, Manikanta.T ${ }^{4}$, Sudarshana.B ${ }^{5}$ \\ Department of Civil Engineering \\ Dr.T. Thimmaiah Institute of Technology, KGF, Karnataka, India \\ principaledrttit.edu.in
}

\begin{abstract}
Nowadays, water scarcity is the most hazardous threaten to the world and a major problem factor in future. Water sources both in surface and ground level are decreasing day by day due to human and natural activities. So, there is a necessity to recycle waste water for the future generation of the world, to avoid such conflicts related to water. All educational institutions do not have proper treatment unit for treating the sewage created by it. So, it is necessary to construct a sewage treatment plant. The project deals with the planning and designing of sewage treatment plant for Dr. T. Thimmaiah Institute of Technology (Dr. TTIT) college campus. Sewage treatment is the process of eliminating contaminants from waste water that is household sewage, both runoff effluents domestic waste. It includes physical, chemical and biological processes to remove contaminants and produce treated waste water. Modern tool usage such as Auto cad and MS excel will be used in the designing process. The recycled water can be used for various purposes like water to gardening, toilet flushing, farming and other requirements.
\end{abstract}

Keywords: Characteristics, Design, Dimension, Sewage, STP, Physical test, Chemical test.

\section{Introduction}

Next to air, the most important requirement for the existence of human life is water. Water is essential for life; despite this, it is taken for granted in various regions of the world. The available fresh water in the world is less than $1 \%$ of all the water on earth, so it is extremely important to use the water resources efficiently and recycle it. Sewage treatment is the process eliminating contaminantsfrom municipal waste water, containing mainly household sewage and surface runoff. Physical, chemical, and biological processes are implemented to eliminate contaminants and produce environmentally safer treated waste water[3][4]. After these processes the treated water can be used for gardening, toilet flushing and other requirements. 


\section{Existing Work}

Several literature papers have been studied and analyzed for the design of each unit for the sewage treatment plant. There are several drawbacks in the existing works that have been identified. In one of the papers [1], the authors have mentioned the comparison studies of three STP's and two of the STP's did not remove TDS which is insufficiency of the STP's. Due to this a RO system had to be installed. In [2], this project the sewage is collected from (63lots+1shopping mall) located in gated community and the total discharge was calculated. Accordingly, the STP was designed. In [5], due to steady increase in the population it resulted to access sewage pollution. So, to avoid this problem STP was designed in the locality. In, a sewage treatment plant was designed based on the population of the college. Various processes for removing contaminants were carried out. Later treated water was used for toilet and farming under medical and non-medical paradigms [7][8].

\section{Proposed Work}

Sewage treatment is a process of eliminating contaminants from waste water. It uses physical, chemical and [6] biological process to eliminate contaminants. Sewage is a collection of waste water from occupied area and carrying it to disposal point. The main objective of various sequential units of a sewage treatment plant, is the removal of nuisance causing compounds and changing the characteristics of the sewage water to produce disposable effluent without causing harm and pollution to water resources. Waste water which is not properly treated may eventually find its way into water source and spread water borne diseases. 


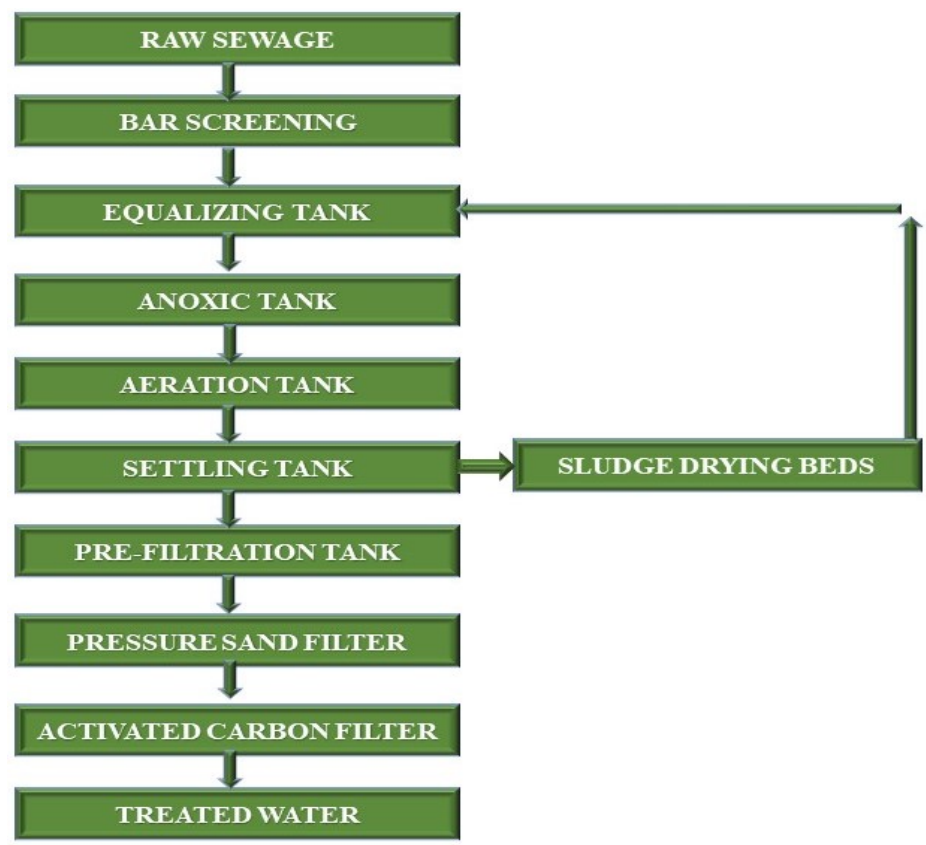

Fig 1: Flow diagram of STP

\section{Design Consideration}

\section{Analytical and numerical model solutions}

At 2020, Total Population $=1050$

It is designed for future population. Hence, after 30 years, that is 2050 population; $\mathrm{Pn}=1050 \mathrm{e}^{\wedge} \mathrm{k}(\mathrm{t} 2-\mathrm{t} 1) \mathrm{t} 2=2050 \quad \mathrm{t} 1=2020, \mathrm{Pn}=4705$ let's consider 4750 population Water utilized $=4750 \mathrm{X}(90 / 100) \mathrm{X} 150=641250 \mathrm{LPCD}=641.250 \mathrm{KLD}=641 \mathrm{~m}^{\wedge}$ $3 /$ day Average waste water generated $=85 \%$ water supplied $=0.85 \times 0.6412=0.545$ $\mathrm{MLD}=545.02 \mathrm{KLD}$ Average waste water per hour=545.02/24 $=22.70 \mathrm{~m}^{\wedge} 3 /$ hour Peak Factor $=3$ Maximum capacity of flow $=22.70 X 3=68.1 \mathrm{~m}^{\wedge} 3 /$ hour $=0.0189$ $\mathrm{m}^{\wedge} 3 / \mathrm{sec}$

\subsection{Designing collection pit}

Required retention time $=2$ hour Average design flow $=22.70 \mathrm{~m}^{\wedge} 3 /$ hour

Collection sump capacity $=2 \times 22.7=45.4 \mathrm{~m}^{\wedge} 3$, Assume depth of liquid $=3.5 \mathrm{~m}$

Required area for collection pit $=45.4 / 2=22.70 \boldsymbol{m}^{\wedge} \mathbf{2}$, Let us consider a circular 
tank. Next, $22.70=\pi r^{\wedge} 2 \mathrm{r}=\operatorname{root} 22.70 / \pi=2.60 \mathrm{~m}$

\subsection{Calculation for Screening}

Qmax $=0.0189 \mathrm{~m}^{\wedge} 3 / \mathrm{sec}$ Assume spacing $\mathrm{b} / \mathrm{w}$ the bar $=20 \mathrm{~mm}$ bar inclination $=80$ degree Average velocity of sewer $=0.8 \mathrm{~m} / \mathrm{sec}$, Net inclined area ae parallel flow $=$ $0.03,0.0189 / 0.8=0.024 \mathrm{sq} . \mathrm{m}$ Total inclined area $=0.024 \times 1.5=0.036 \mathrm{sq} . \mathrm{m}$, Gross vertical area required $=0.036 \times \sin 80=0.0351$ sq. $\mathrm{m}$ Consider submerge depth $=$ $0.2 \mathrm{~m}$ Channel width $=0.0351 / 0.2=0.2$, Provide 20 bars of $10 \mathrm{mmX} 50 \mathrm{~mm} @ 20 \mathrm{~mm}$ chair spacing, length of the chamber screen will be $60 \mathrm{~cm}$

\subsection{Designing Equalization Tank}

Flow design $=(2.5 \times 0.545) / 2=0.6812 \mathrm{MLD}=681.2 \mathrm{~m}^{\wedge} 3 /$ day, Loading surface $=$ $1100 \boldsymbol{m}^{\wedge} \mathbf{3}$ / sq. $\mathrm{m} /$ day, Surface loading is reduced to $800 \mathrm{~m}^{\wedge} 3 /$ sq. $\mathrm{m} /$ day to avoid short circuiting and turbulence. Required area $=681.2 / 800=0.85$ sq. $\mathrm{m}$ Provide $1 \mathrm{~m}$ dia. Detention time of circular chamber $=60 \mathrm{sec}$. volume $=(681.2 \times 60) /$ $(24 \times 3600)=0.4730 m^{\wedge} 3$, Depth of liquid $=0.473 / 0.85=0.56$

Free board $=0.3$ Size of equalization tank $=1 * 0.86$

\subsection{Designing Anoxic Tank}

Average discharge $=681.2 \mathrm{~m}^{\wedge} 3 /$ day, Detention period $=2$ hours, Capacity of tank $=(681.2 \times 2) / 24=56.76 \mathrm{~m}^{\wedge} 3$, Length $\mathrm{x}$ breath $\mathrm{x}$ depth $=56.76 \mathrm{~m}^{\wedge}$, Assume the depth $=3.5 \mathrm{~m}$ and length $=2.5 \mathrm{~b}$, Volume of the tank $=2.5 \mathrm{~b} \times \mathrm{b} \times 3.5=56.76 \mathrm{~m}^{\wedge} 3$ $8.75 \mathrm{~b}^{\wedge} 2=56.76 \mathrm{~B}=2.54 \mathrm{~m}, \mathrm{~L}=2.5 \times 2.54=6.46 \mathrm{~m}$ Size of anoxic tank $6.5 \times 2.5 \times 3.5$

\subsection{Designing Aeration Tank}

Flow to tank $=0.6812 \mathrm{MLD}, \mathrm{Q}=681.2 \mathrm{~m}^{\wedge} 3 /$ day Assume BOD of waste water entering aeration tank $=180 \mathrm{mg} / \mathrm{L}$, Assuming that screening eliminates negligible BOD, BOD Left over in effluent $=Y E=13 \mathrm{mg} / \mathrm{L}, \mathrm{B}=180-13=167 \mathrm{mg} / \mathrm{L} \mathrm{Re}-$ quired minimum efficiency in the activated plant $=167 / 180=0.92=92 \% \mathrm{OK}$, Assume a suitable value of MLSS ' $\theta c^{\natural}=3500 \mathrm{mg} / \mathrm{L}$ Is used for designing the volume aeration tank. $\mathrm{F} / \mathrm{M}$ ratio $=0.5$, Therefore, $\mathrm{Q}=681.2 \mathrm{~m}^{\wedge} 3$ day, $\mathrm{V}=$ ? $Y 0=180 \mathrm{mg}$ $/ \mathrm{L} \mathrm{X}(\mathrm{T})=3500 \mathrm{mg} / \mathrm{L}, \mathrm{F} / \mathrm{M}=0.3=(681.2 \times 180) / \mathrm{v} \times 3500 \mathrm{~V}=(681.2 \times 180) /$ $(3500 \times 0.5)=70.06 \mathrm{~m}^{\wedge} 3$, Dimension of aeration tank Let's consider an aeration tank of liquid depth $3.5 \mathrm{~m}, 4.5 \mathrm{~m}$ breadth then tank length $=\mathrm{V} / \mathrm{BxD}$ $=70.06 /(4.5 \times 3.5)=4.44 \mathrm{~m}$, Therefore, volume provide $=4.5 * 4.5 * 3.5=70.89 \mathrm{~m}^{\wedge} 3$ 


\subsection{Designing Clarifier}

Avg. Flow $=545.02 \mathrm{KLD}=545.02 \mathrm{~m}^{\wedge} 3 /$ day Recirculated flow, Assume $50 \%=$ $272.51 \mathrm{~m}^{\wedge} 3$ /day, Sum inflow $=545+272.51=817.51 \mathrm{~m}^{\wedge} 3 /$ day, Consider hydraulic detention time $=2$ hours, Tank volume $=817.51 \times 2 / 24=68.12 \mathrm{~m}^{\wedge} 3$ Consider depth of liquid $=3.5 \mathrm{~m}$, Actual area provided $=19.46 \mathrm{~m}^{\wedge} 2$ Surface area to be provided $=545.02 / 20=19.13=27.25 \mathrm{~m}^{\wedge} 2$, Circular tank diameter $\mathrm{D}=\operatorname{root} 27.25 \times 4 / \pi=5.89$, let us take $5 \mathrm{~m}$, Provide liquid depth $3.5 \mathrm{~m}$, hopper slope will be 1 in 12 . Free board is $0.3 \mathrm{~m}$.

\subsection{Designing Sludge Drying Beds}

Solid material $=1.5 \%$, Specific gravity $=1.015$, Sludge volume $=1251.5 \% X$ $11000 \times 1.015=8.2 \mathrm{~m}^{\wedge} 3$ Total cycles in one year $=33$, Time period for one cycle $=365 / 33=11$ days. Sludge volume $=8.2 X 11=90.2 \mathrm{~m}^{\wedge} 3$ Required area of beds for spreading for layer of $0.3 \mathrm{~m} /$ cycle $=90.2 / 0.3=300.67$ Consider 4 beds of $1.2 \mathrm{mX} 3.5 \mathrm{~m}$ thus considering $=16.8 \mathrm{~m}^{\wedge} 2$

\subsection{Designing clean water tank}

Final erection tank detention time $=11.5 \mathrm{hrs}$, volume of erection $\tan \mathrm{k}=55 \mathrm{~m}^{\wedge} 3$, final erection tank dimension $=4.5 \mathrm{mx} 3.5 \mathrm{~m}$

\section{Conclusions}

[1] The project deals with the issue of untreated sewage water disposal and design parameters of sewage treatment plant for Dr. TTIT college campus. The design has been done for future predicted population of 30 years (2020-2050). The sewage treatment plant is designed to meet the demands and needs of appropriately 4750 population with a large time periodThe future scope of sewage treatment plant for the campus is that water can be further used for gardening, toilet flushing and irrigation, if it is sufficiently clean, we can also be used for ground water recharge.

\section{Reference}

1. Paljornamgyal and K. Prasanna"Study on improving the efficiency of the sewage treatment plants at SRM university,india" 2014.

2. ShrirangVrushali and ChatterjeeKaustav"Sewage treatment and reuse:A step towards water conservation"IJERT ISSN:2348-604X,Volume -1 Issue-2 (2014).

3. Murthy Polasa and BharathiBhattu "Design of a sewage treatment plant for a gated community, AP, India” (IJERT) ISSN: 2278-0181 Vol. 3 Issue 4, April - 2014. 
4. Aswathy.M and Hemapriya "Analysis and designs of sewage treatment plant (STP) of apartments in Chennai” (IJPAM) Volume 116 no.13 2017,157-163, ISSN:1311-8080 2017.

5. M.Bhargavi and AnathaRao"Analysis and designs of sewage treatment plant: case study on Vizianagaram municipality"(SSRG-IJCE) Volume 5 issue 4-april 2018.

6. Kumar, S.S., Ahmed, S.T., Vigneshwaran, P. et al. Two phase cluster validation approach towards measuring cluster quality in unstructured and structured numerical datasets. $\mathrm{J}$ Ambient Intell Human Comput (2020). https://doi.org/10.1007/s12652-020-02487-w

7. K. D. Singh and S. T. Ahmed, "Systematic Linear Word String Recognition and Evaluation Technique," 2020 International Conference on Communication and Signal Processing (ICCSP), Chennai, India, 2020, pp. 0545-0548, doi: 10.1109/ICCSP48568.2020.9182044

8. Ahmed, S.T., Sandhya, M. \& Sankar, S. A Dynamic MooM Dataset Processing Under TelMED Protocol Design for QoS Improvisation of Telemedicine Environment. J Med Syst 43, 257 (2019).https://doi.org/10.1007/s10916-019-1392-4 